\title{
Alternative Communications: the USSR Experience and Modern Transformation
}

\author{
O. Melnykova-Kurhanova \\ Mariupol State University \\ Corresponding author.E-mail: mel05@ukr.net
}

Paper received 12.03.19; Accepted for publication 25.03.19.

https://doi.org/10.31174/SEND-HS2019-199VII33-21

\begin{abstract}
This article researches and compares the features of alternative communications in the Soviet and modern periods. The author analyses the works of Ukrainian and foreign scholars. The concept of dissident and alternative communications is considered. The research method is interviewing participants and witnesses of the dissident movement in Ukraine: professional communicators, journalists, and publicists. Their interpretation relates the events of 1960-1980s to Ukraine's today.

Keywords: alternative communications, dissident communications, samizdat (self-publishing, underground press), tamizdat (publishing abroad), alternative channels of communication, transmedia.
\end{abstract}

Introduction. There is a large amount of information in today's information space. When choosing a communication channel and high-quality content, this may pose a problem. Therefore, an ability to work with information, to think critically, to use various communication channels and to acquire the fact check competence is quite a value. Alternative sources of information are developing on the Internet and getting more and more popular. Historical experience (particularly, dissident communications in the 1960-80s USSR) remains pertinent for understanding operation of modern alternative information platforms, channels and sources.

Consider the following types of communication. Alternative communication is communication representing an alternative to dominant/official opinions of the authorities and/or the media. Alternative communication can take place both in democratic and totalitarian or authoritarian societies - depending on the political situation in the country. Alternative communication is typical for protest movements and opposes openly the official position of the authorities. Being social communication, dissident communication has got its own tools, methods and principles for distributing alternative or officially prohibited information, knowledge and ideas through alternative, often secret, channels. It means that they were banned in a closed society, constituted an alternative to the official media, published information suppressed by the authorities, new knowledge and counter-opinions. Above all, dissident communications are usual for totalitarian and authoritarian states. The decisive features of dissident communications are as follows: alternative channels of information; alternative content; novelized and opinionbased journalism; anonymity of the authors or disclosure of the names of the author and the like-minded signatories; irregular output of information; spontaneous distribution of the texts banned by the authorities; undefined quantitative and qualitative indicators of mass audience; countermeasures, counterarguments, reframing, etc. The dissident communications are distinguished from other modern alternative communications for channels selection, transformation of the state's political regimes, as well as diversity of content and the ways it is presented.

Reviewing research-related publications The problem under research was considered by F. Kind-Kovacs, A. Lovejoy, J. Labov, S. B. Snyder, K. Moloney,
S. Mikkonen, S. Westlake, G. Pocheptsov, N. Dziomba, $\mathrm{Yu}$. Bondarenko and others.

F. Kind-Kovacs and V. Labov are researching such alternative information sources as samizdat and tamizdat. They believe that the ideas propagated by samizdat publications led to the active resistance movement in Ukraine and Slovakia in the late 1980s. Today, the impact on citizens has become the domain of the Internet and transnational communications, as modern strategies of alternative media and culture are evaluated in the light of the recent political events [5]. By the authors, the Internet and the blogosphere are the alternative media.

Among such modern current trends of the information and communication space as multimedia, cross-media and transmedia, the latter can be distinguished as a modern platform showing some features of dissident communications. According to K. Moloney, it is "a single world of narration, the world of many stories, many forms and many channels" that forms and groups the audience according to some or other features [8].

As for tamizdat, it can be identified as transnational communication as well. The effect of the repeated transmission of a single text across borders, different environments, professional and amateur editors "leads to the accumulation of "noise" characterizing the text's peculiarities" [5]. Printing style, graphics, etc. make it possible to read, for example, a tamizdat text. But it also can be edited. It is important to use critical thinking to detect and decode the "noise" created during the transfer of material. It is also necessary to take into account the effect of this "noise" on the users of tamizdat information products. It allows distributing (publishing or broadcasting) texts and developing the public demand for other art genres and forms [5].

Yu. Bondarenko states that "the alternative media have abandoned communication in one direction and allow readers to create a media content independently aimed at a special target audience - a counter-publicity - representatives of various social groups and subcultural groups [1, p. 16].

This paper's objective is to compare the features of alternative and dissident communications. Meeting the objective requires the following tasks to be done:

- analysing domestic and foreign scientific works on the subject under research; 
- identifying the specifics of alternative communications;

- comparing alternative channels of communication of 1960-80s to modern ones.

Materials and methods. For the purpose of the research, the method of interviewing participants and contemporaries of the dissident movements (20 respondents, including V. Chornovil, L. Tanyuk, Ye. Sverstiuk, O. Shevchenko, V. Ovsienko, B. Goryn, Ya. Kendzor, I. Kalynets, R. Dovgan and others) was used. The purpose of the interview was to identify methods and ways of creating and distributing alternative information in the Soviet Union. To identify the functions of alternative and dissident communications in Ukraine, descriptive and systematic methods were used. Due to the system approach and classification method, we managed to identify the features of both dissident communications in the USSR and modern alternative communications in Ukraine.

Discussing results. Taking into account the peculiarities of the alternative press' functions, the potential audience is formed as a group that has the demand for alternative information. Samizdat distributed the alternative content as petitions, appeals, complaints, protests, requests, communications, applications to official bodies, etc. Oral dissident communications took place at dissident meetings at public places or civic organizations. Besides, tamizdat publications and reports on repressions of the intellectuals and political prisoners were sent to Radio Liberty, Voice of America, Reuters and to the periodicals of Western Europe and the United States.

In the transnational aspect, the role of foreign radio stations in the distribution of texts beyond the Iron Curtain is also important. Dissident communications circulated in the USSR and the western countries through the network of communicators whose reports were broadcast by the foreign radio stations banned in the USSR. Despite the Cold War between the USSR and the USA, Radio Liberty managed to reach, by soft diplomacy, the platform of a liberal dialogue with the Soviet Union media. Broadcasting - particularly, of samizdat texts - provided for some of the main goals of modern web-cultural activities (e.g. digital tamizdat) [3].

A. Lovejoy pays attention to such alternative channels as magnitizdat (magnet tape publishing, e.g. records of bard songs, poems, journalistic performances, etc.) In 1986-1989, in Czechoslovakia, samizdat video magazines were published. The researcher considers biographical narratives as a field of personal meanings embedded into samizdat and tamizdat publications [6, p.72]. An author's role is changing gradually today; unprofessional communicators such as bloggers and civic activists become leaders in opinions and have their own audience on the Internet. Blogging becomes an alternative to professional news journalism.

In her work titled "Human Rights and the End of the Cold War", Sarah B. Snyder researches the role of human rights activities during the signing of the Helsinki Final Act in 1975. The transnational network of human rights activists in the Soviet Union and Eastern Europe has made this topic central to East-West diplomacy. Sarah B. Snyder believes that this network of human rights communicators has influenced governments' policies and contributed to the emergence of the organized dissident movements in Eastern Europe and to the improvement of methods for the protection of human rights in the Soviet Union: "The Commission (source of Helsinki) received and translated many samizdat documents and forwarded them to other CSCE states and interested groups. As such, it played a critical role, connected different activists and policymakers across interests and national lines" [9, p. 50]. With the assistance of the Human Rights Committee in Moscow, the author examines how the topic of human rights protection was covered in the USSR using the Chronicle of Current Events samizdat magazine that played an important role in documenting human rights violations in the Soviet Union. Attention is paid to the Soviet system, in particular, labour camps, where political prisoners suffered from poor medical care, malnutrition, severe punishments and exhausting labour standards.

We can state that a peculiarity of alternative and dissident communications is anonymity. On the Internet, it is also difficult to identify an anonymous author. Yet, in the mid-1960's, journalist dissidents started signing their texts. On the Internet, bloggers and other communicators act under their own names or nicknames. Both in the Soviet period and today, information products circulate in the information and communication space uncontrolled by their authors. Editing, proofreading and choosing an information platform are accidental. For both samizdat/tamizdat and the Internet, it is impossible to define clear quantitative and qualitative indicators of the audience. Transmedia, however, define their potential audiences by one or another criterion. Dissenting communications were directed at separate groups of people sharing same interests, views and values. Alternative media's target audiences are broad since it is difficult to track what channels and platforms this or that material was published with.

The reason for the emergence of dissident and alternative media was violation of the freedom of speech and other human rights, which resulted in alternative channels of communication offering the content of protest, opposition and criticism. In authoritarian or totalitarian states, where dissidents are being persecuted and the number of political prisoners is increasing, the knowledge of dissident communications and alternative channels and communication platforms is of special importance.

In 1970-1980, the dissidents distributed open letters, statements, appeals, letters of protest, etc. signed by their authors and the like-minded. Today, online electronic signature petitions are valid.

As effective communicators, dissidents worked with a group audience. For example, a modern blogger being an alternative opinion leader have its own online audience of those who refuse using traditional channels of communication.

A common feature of tamizdat/samizdat and transmedia is a large number of channels to broadcast alternative content. Spontaneous editing and distribution of alternative information change the way information is typically presented.

When comparing the alternative media countermeasures in the USSR and today's Ukraine, we should mark "jamming" of TV and radio signals in the eastern Ukraine during military operations and blocking online periodicals and social networks publishing alternative opinions on the 
totalitarian regime. As a result, some "alternative" Internet resources cannot be accessed, and some just close up. "Jamming" TV and radio broadcasts is used in the occupied regions of the Donbas; in Ukrainian cities and villages bordering the so-called republics, the access to Ukrainian media is restricted.

Samizdat reflects the methods of information war between Ukrainian dissidents and the KGB. For example, samizdat authors participated in discussions standing on Marxist-Leninist positions, which corresponded to their outlooks. Therefore, dissident journalism often refers to the Constitution of the USSR and the works of Lenin, Marx and Engels. To provide conditions for national revival and independence, dissident writers resorted to citing official documents and historical examples.

Foreign periodicals published samizdat magazines; dissident texts were broadcast by Radio Liberty, Voice of America, BBC, Radio Vatican, etc. Since it was the period when the Cold War started, the authorities frowned at this cooperation. The outlaw short-wave radio stations appeared to be the most effective channel to distribute alternative content: "For Radio Liberty, regular mass arrests of Ukrainian intellectuals meant that, apart from publication of dissident works, attention should be paid both to the works of the Soviet dissidents and their lot, since the interest in the Sixtiers' works means the interest in their lives" [3, p. 39]. Thus, foreign and banned radio stations broadcast dissidents' texts and reported arrests of dissenters. Dissident communications were getting more and more effective; some alternative messengers were of the same level as the USSR official media. In his research, Steve Westlake outlines Radio Liberty's main topic blocks: "After some early experimentation with format, I settled on producing six episodes of roughly 25 minutes each, with each episode focusing on the presentation and subsequent analysis of RL broadcasts which focused on a particular Cold War topic or event. The six chosen topics were as follows: The Death of Stalin; The Space Race; The Vietnam War; Human Rights and the Helsinki Accords; The Chernobyl Disaster; and the Collapse of the Soviet Union" [10, p. 10].

The methods and techniques of the dissidents' informational confrontation of the official mass media of the totalitarian state proved to be effective: during Perestroika, many public and human rights movements were started, many political organizations were established, alternative media were popularized, and many declarations, open letters and other notes were addressed to high officials. In today's Ukraine, public activists play an important role in society; in particular, they organize various human rights movements, publish online petitions and distribute alternative content. Today's Internet media position themselves as alternative media and offer this or that piece of information or opinion for sale. Regular columns, expert materials and leaks of classified information are getting more and more popular. Currently, alternative media in democratic countries are on open access online. According to Francis Fukuyama, "Our present world is simultaneously moving toward the opposing dystopias of hypercentralization and endless fragmentation. China, for instance, is building a massive dictatorship in which the government collects highly specific personal data on the daily transactions of every citizen. On the other hand, other parts of the world are seeing the breakdown of centralized institutions, the emergence of failed states, increasing polarization, and a growing lack of consensus over common ends. Social media and the Internet have facilitated the emergence of self-contained communities, walled off not by physical barriers but by shared identities"[4].

The research includes 20 interviews with the editorial staff of the leading samizdat magazines ("Ukrainsky Visnyk", "Yevshan-Zillya", "Porogy", etc.), professional journalists of the 1960s-1980s, participants in the dissident movements and the eyewitnesses. The interview key topics were: the struggle for human rights, the national idea and original world view and credibility of information. Dissident communications were a part of the sociocultural space in a closed society. During the interview, the respondents' recollections were determined by their life experience and current social position. The interviewees talked on the substitution of notions during perestroika, the role of samizdat, news by banned radio stations, mass public speeches at meetings, rallies and demonstrations.

According to Oles Shevchenko, the listeners were notified of when it is better to turn on their radios in order to avoid possible broadcast jamming by the authorities. Beside entertainment programmes, news blocks related to human rights activities and dissidents' journalistic essays and fiction were broadcast - yet with delay, in order to avoid jamming [2, p. 52]. According to Grygorii Panchuk, a Radio Liberty Munich correspondent, samizdat broadcasts were at least a moral support both for the writers and their readers. They could see that we knew about them; they could see they weren't totally on their own. I, for one, try to avoid communication as a way to protrude my opinions to the listeners; for me, it is rather the way to inform the audience - that is, to form an opinion on the basis of realities, contradictions and news. The concepts of "communicating" and "informing" are not the same. And it doesn't take a lot time to find an example. Consider the role of today's Russian media. They communicate with the population rather than inform them. Actually, they just muddle people's minds. Today, the word "communication" is an ideologeme perverting people's opinions." [2, p. 112]. While most foreign radio stations were banned and jammed, the potential audience of samizdat's readers was of a group nature; the audience were samizdat editors, authors and correspondents themselves.

Conclusions This dissident communication research used the interview method to identify modern interpretation of the Soviet dissident culture and its impact on the present (for example, the role of the Internet as an alternative information channel, electronic signature petitions and declarations, bloggers as alternative opinion leaders, etc.) The interviewees focused on public readings and popularization of the samizdat literature among the Ukrainian intellectuals, listening to banned radio stations, broadcasting samizdat materials and the role of the human rights documents signed by dozens of people. Some interviewees (Igor Kalynets, Valentyna Chornovil) expressed the opinion that Ukrainian dissidents rather used the ideological apparatus to reinforce their ideas than opposed it. They also considered important distribution of fiction and journalistic works of banned authors. Mostly, dissident 
media had group audiences united by same views and friendly relations. Modern alternative media's publications or broadcasts criticise pro-government structures or media and oppose it openly. In the USSR, persecution, audio interception administrative controls and arrests were the methods to confront the Ukrainian dissidents. Yet, "jamming", arrests, erasure of personal data or copyright texts on the Internet are still used today.

Apart from the changes in the political regime and "liberalization" during the perestroika, the respondents were also talking of the changes in frames, development of negative senses associated with the ideology of communism and socialism, stalinism, the Party, Soviet history etc. and positive senses associated with obtaining new information on foreign countries and their culture, demo- cratic values, human rights activists and unexplored facts of history. All the respondents argued for their illegal dissident information and communication activities as a struggle for their ideas and ideals (truth, justice, human rights and freedom of speech, etc.) Rather than tough actions, their weapons were those dissident communications, literature works and documents within the information space that became of public capacity and opposed repressions and other violations of human rights.

Therefore, the key peculiarities of alternative and dissident communications are alternative content and alternative channels. Modern alternative communications' features are a large number of channels, different ways of presentation, original content and opinion leaders known for their unique style.

\section{ЛІТЕРАТУРА}

1. Бондаренко Ю. Альтернативна преса сучасної Німеччини (особливості функціонування, редакційна політика, місце в національнійсистемі медіа): автореф. дис. канд. наук 3 соц. комунікацій: 27.00.04. Львів: Львів. нац. ун-т ім. I. Франка [б. в.], 2017. 20с.

2. Мельникова О.С. Дисидентські комунікації в Україні (1960 - початку 1990 рр.): інтерв'ю $з$ учасниками та свідками: хрестоматія для студентів спеціальності 061 «Журналістика». Маріуполь: Центр друку "Калейдоскоп", 2018. $122 \mathrm{c}$.

3. Ремовська О. Говорить Радіо Свобода. Історія української редакції. К.: Вид. дім «К-Могилян. акад.», 2014. 163 с.

4. Fukuyama, Francis (2018). Against Identity Politics URL: https://www.foreignaffairs.com/articles/americas/2018-0814/against-identity-politics-tribalism-francis-fukuyama.

5. Kind-KovácsF., Labov J. (2015). Samizdat, Tamizdat, andBeyond: Transnational Media During and After Socialism. NY: Berghahn Books, 2015. URL: http: //www.berghahnbooks.com/title/Kind-KovacsSamizdat.

6. Kind-Kovács F., Lovejoy A., Labov J., etc (2013). "Radio Free Europe and Radio Liberty as the 'echo chamber' of ta-

mizdat" // Samizdat, Tamizdat and Beyond. Transnational media during and after socialism. New York: Berghahn Books 2013. P. 70-91.

7. Mikkonen, S. (2010). Radio Liberty - the enemy within? The dissemination of western values through us cold war broadcasts. In Europe - Evropa. Cross-cultural dialogues between the West, Russia, and Southeastern Europe. (pp. 243-257). Acta Universitatis Upsaliensis. Studia multiethnica Upsaliensia (18). Uppsala: Uppsala University Press.

8. Moloney K (2011). Multimedia, Crossmedia, Transmedia... What's in a name? URL: https://transmediajournalism.org/2014/04/21/multimediacrossmedia-transmedia-whats-in-a-name.

9. Snyder Sarah B. Human rights Activism and the end of the Cold War. Cambridge, Cambridge University Press, 2011. $287 \mathrm{p}$.

10. Westlake, Steve (2018). "Speaking to the Soviets": podcasting, public diplomacy and the blinken open society archives' Radio Liberty audio collection. Corvinus Journal of International Affairs, Budapest, 2018, P. 4-11.

\section{REFERENCES}

1. Bondarenko Yu. S. Alternative Press of Modern Germany (functioning peculiarities, editorial policy, place in the national media system): Thesis for a Candidate Degree in Social Communication: specialty 27.00.04. National University of Lviv, Lviv, 2017. 20 p.

2. Melnykova O. S. Dissident communications in Ukraine since 1960 s to the beginning of 1990s.: interview with participants

and witnesses: textbook for students of the specialty 061 "Journalism". Mariupol: The Kaleidoscope Print Center, 2018. 122 p.

3. Removska O. Says Radio Liberty. History of the Ukrainian edition. Kiev: Publishing House "Kyiv-Mohyla Academy", 2014. 163 p. 